\title{
Treatment of spondyloarthropathies with antibodies against tumour necrosis factor $\alpha$ : first clinical and laboratory experiences
}

\begin{abstract}
Jürgen Braun, Jian Xiang, Jan Brandt, Hardy Maetzel, Hildrun Haibel, Peihua Wu, Siegfried Kohler, Martin Rudwaleit, Stefanie Siegert, Andreas Radbruch, Andreas Thiel, Joachim Sieper
\end{abstract}

Department of Medicine, Rheumatology, Benjamin Franklin Hospital, Free University Berlin, and German Rheumatology Research Centre, Berlin, Germany

Correspondence to: Professor Braun (jbraun@zedat.fu-berlin.de)
Drug treatment of patients with spondyloarthropathies (SpA), especially ankylosing spondylitis (AS) has limited capacity. ${ }^{1}$ Pain but not disease activity can be reduced by nonsteroidal anti-inflammatory drugs (NSAIDs), in severe cases very high doses are needed. ${ }^{2}$ By examination of sacroiliac biopsy specimens we have shown that, in correlation to disease activity assessed by magnetic resonance imaging (MRI), $\mathrm{T}$ cells and macrophages ${ }^{3}$ and tumour necrosis factor $\alpha(\mathrm{TNF} \alpha) \mathrm{mRNA}^{4}$ and protein (fig1) but no bacterial $\mathrm{DNA}^{5}$ is present in these joints that are pathognomonically involved in AS. $^{6}$ Furthermore, anti-TNF $\alpha$ monoclonal antibodies (mAb) have recently been shown to be efficacious in Crohn's disease ${ }^{7}$ - a disease that is strongly linked to AS because more than $60 \%$ of AS patients have clinically often silent gut lesions resembling Crohn's colitis. ${ }^{8}$ Furthermore, in another chronic inflammatory rheumatic disease, rheumatoid arthritis (RA), anti-TNF treatment has proved efficacious and even seems to prevent joint damage. ${ }^{9}$

$\mathrm{TNF} \alpha$ is a cytokine that is mainly produced by monocytes and macrophages and to a lesser degree by $\mathrm{T}$ cells. There are two specific receptors, a $55 \mathrm{kDa}$ and a $75 \mathrm{kDa}$ present on many cell types. $\mathrm{TNF} \alpha$ mediates inflammatory and immunoregulatory activities. Effects on cells such as lymphocyte activation and fibroblast proliferation, on mediators such as other cytokines like interleukin 1(IL1), IL6 and IL8, chemokines, prostaglandins, metalloproteinases, on the vasculature by promoting angiogenesis and on upregulation of adhesion molecules and transendothelial migration of

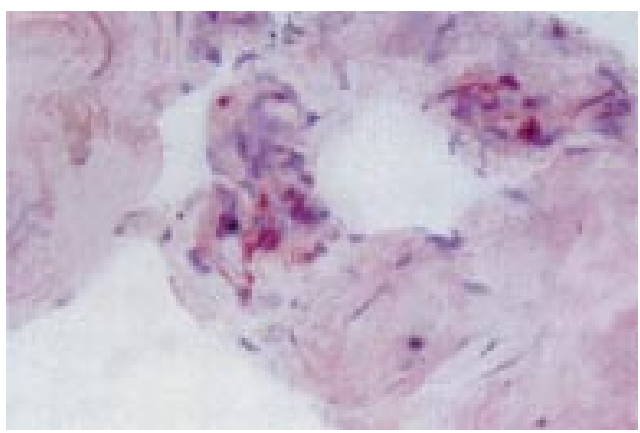

Figure 1 Immunohistological examination of a sacroiliac biopsy specimen obtained by computed tomography guided biopsy of a 23 year old patient with ankylosing spondylitis, four years disease duration, with inflammatory back pain grade 6 on a visual analogue scale $(0-10)$. The red staining indicates a mononuclear cell positive for $T N F a$ (APAAP staining technique). leucocytes are well described. In in vitro and in animal models $\mathrm{TNF} \alpha$ causes fever, pain and cachexy, mobilises calcium from bone and induces apoptosis (for review see Beutler ${ }^{10}$ ). All theses mechanisms are proinflammatory but, moreover, $\mathrm{TNF} \alpha$ has important physiological functions in immune responses against pathogens and may contribute to suppression of autoimmunity and malignancy. ${ }^{11}$ Blocking of these functions might lead to undesired side effects.

Infliximab, a chimeric human murine monoclonal anti-TNF $\alpha$ neutralising antibody of IgG1א isotype (Infliximab, cA2, Remicade, Essex/Centocor), was used for the first time in Berlin $^{12}$ and later also in a study from Ghent/Belgium ${ }^{13}$ to treat AS patients. There are other agents acting against $\mathrm{TNF} \alpha$ such as a $\mathrm{TNF} \alpha 75 \mathrm{kDa}$ receptor IgG1 fusion protein (Etanercept, Enbrel, Wyeth/Immunex), which proved effective in RA patients who were not sufficiently treated with methotrexate alone. ${ }^{14}$ It is unclear whether Etanercept works in Crohn's disease but it seems to work in other SpA (see below).

In the Berlin study, 11 patients who fulfilled the 1984 modified New York criteria for AS were included. ${ }^{12}$ All patients were in an acute phase with high disease activity and severe pain quantified by the evaluated outcome parameter Bath AS Disease Activity Index (BASDAI, 15) and a Visual Analogue Scale (VAS) for spinal pain. Patients were included in the study if they had a BASDAI score $>4$ plus a VAS score for pain $>4$. Ten patients were male, one female, mean age $36(27-56)$ years with a median disease duration (date of first symptoms) of 5 (0.5 -13) years. Five patients had relevant radiological changes of the spine with three or more syndesmophytes and/or fusions of vertebrae. Ten patients were HLA B27 positive. The study drug infliximab was infused intravenously in a dose of $5 \mathrm{mg} / \mathrm{kg}$ at three time points (week 0,2 and 6). Disease modifying antirheumatic drugs (DMARDs) and corticosteroids had been withdrawn four weeks before the study started. Patients who were allowed to take NSAIDs had to record the daily dose. The following end points were assessed: the BASDAI, the Bath AS functional index (BASFI), a $10 \mathrm{~cm}$ VAS for spinal pain, the Bath AS metrology index (BASMI), quality of life as measured by the short form (SF)36 instrument, $C$ reactive protein (CRP) and IL6 serum levels. Patients returned for follow up assessments every two 
weeks until week 8 and then every four weeks until the final visit at week 24 .

The female patient had to be withdrawn from the study eight days after the first infusion because of a generalised rash. The remaining 10 patients experienced dramatic improvement starting already on the first day after the first infusion. The median improvement of BASDAI was $70 \%$ after four weeks, 9 of 10 improved $>50 \%$. The immediately occurring effects persisted for more than six weeks after the third infusion in 10 of 11 patients. The median duration of improvement before the BASDAI reached $80 \%$ of the pretreatment value was 9.5 weeks after the third infusion (range 3-14 weeks). The first subjective symptoms were reported after a median of six weeks (range 1-14 weeks). One patient, after constantly active disease over two years, is in permanent remission for to date 16 weeks, one had an early relapse three weeks after the third infusion. In the direct comparison between day 0 and day 43 all parameters showed a statistically significant improvement (median of scores and values for day 1, day 28 and 43): BASDAI from 6.5 to $2.8(\mathrm{p}=0.001)$ and 1.7 $(\mathrm{p}=0.002)$; BASFI from 5.3 to $2.0(\mathrm{p}=0.002)$ and $2.0(p=0.002)$; BASMI from 3.0 to 1.0 $(p=0.031)$ and $1.0(p=0.008)$; VAS for pain from 7.8 to $2.0(\mathrm{p}=0.002)$ and $1.3(\mathrm{p}=0.002)$ and CRP from $15.5 \mathrm{mg} / \mathrm{l}$ to normal range $(<6$ $\mathrm{mg} / \mathrm{l})$ at day $15 \quad(\mathrm{p}=0.006)$ and day 43 $(p=0.004)$ respectively; this was similar for IL6 (median before $12.7 \mathrm{ng} / \mathrm{l}, 4$ and 12 weeks after treatment $<5 \mathrm{ng} / \mathrm{l} ; 6$ of 11 patients had increased levels).

The quality of life measurements showed clear improvement in physical and also social concepts. Two patients had peripheral arthritis of knee and ankle that disappeared two days after the first infusion. The patients used less than $50 \%$ of the NSAID dose taken before; five patients completely stopped taking NSAIDs. After a follow up of 10 months, eight patients are still in the study as two more patients were withdrawn because of significant infusion reactions that were easy to handle but did not permit further treatment with infliximab. To minimise such effects it has to be studied whether methotrexate or azathioprine have to be added to this treatment. Of note, methotrexate is used by a relatively high number of rheumatologists in $\mathrm{AS},{ }^{16}$ although there is little evidence that it is efficacious: not a single controlled study has been performed to date.

The actual situation is that the remaining eight patients would like to receive infliximab about every sixth week because they do not want to wait until the symptoms come back. There is no clear indication of a lack of effect so far.

In the first three months, 5 of 11 patients developed uncomplicated infectious episodes and continued the study: two tonsillitis, two sinusitis (all requiring antibiotic treatment) and one herpes labialis. Some weeks later another patient developed diarrhoea and Salmonella enteritidis was grown from his stool; antibiotic treatment with ciprofloxacin stopped the symptoms and stool cultures have re- mained negative thereafter. Taken together, there seems to be a slight increase of infections in patients treated with infliximab in doses $>3$ $\mathrm{mg} / \mathrm{kg}$. However, there is no indication that this represents a serious concern.

Similarly, in the Belgian study ${ }^{13}$ spinal pain in 7 of 11 AS patients improved significantly at two and six weeks after anti-TNF $\alpha$ treatment given as an induction treatment at week 0,2 and 6; CRP values became normal after treatment. Together $18 \mathrm{SpA}$ patients with peripheral arthritis were treated, mostly successful on a six weeks basis. The AS patients were older and had a longer disease duration compared with the Berlin study. ${ }^{17}$

These open studies suggest that infliximab is efficacious in the treatment of active AS. The results of the study provide some evidence that $\mathrm{TNF} \alpha$ blockade is effective in AS; this seems to be true also in other SpAs. In the Belgian study eight patients with psoriasis were treated with infliximab. Peripheral joint and skin symptoms ameliorated significantly after 7 and 14 days. In another open study ${ }^{18}$ six patients with severe psoriatic arthritis under treatment with methotrexate (15-25 mg/week) received additional treatment with infliximab. All patients developed quick and persistent improvement of joint and skin symptoms.

A randomised study with Enbrel in addition to methotrexate has been performed in a randomised controlled trial in patients with psoriatic arthritis with a very good efficacy. ${ }^{19}$ Thus, blockade of $\mathrm{TNF} \alpha$ seems to be also effective in patients with severe psoriatic arthritis.

Undifferentiated spondyloarthropathy (uSpA) is the most or the second most frequent $\mathrm{SpA}$ subset. $^{2021}$ It is remarkable that no treatment study dealing with this condition has ever been performed to date. The two uSpA patients of the Belgian study ${ }^{13}$ improved similarly to the other SpA. This is in accordance with our experience in three cases with active $\mathrm{uSpA}$. Of note, this included a patient with multilocular enthesitis who significantly improved after infliximab. In conclusion, antiTNF treament seems to be efficacious also in other $\mathrm{SpA}$ subsets with active disease.

There are some interesting effects and partly unexpected findings of anti-TNF treatment on laboratory parameters. Feldmann et al measured increased $\mathrm{TNF} \alpha$ serum concentrations while both soluble TNF receptor levels remained unchanged or increased. However, measuring serum $\mathrm{TNF} \alpha$ is difficult (only $50 \%$ of the RA patients treated had increased levels) because the half life is short and the TNF measured in that study was not in its bioactive state, ${ }^{22}$ which might indicate that immune complexes of soluble TNF and infliximab were measured.

The changes in the $\mathrm{TNF} \alpha$ secretion capacity and in $\mathrm{T}$ cell counts after treatment with infliximab in AS patients were recently investigated in our laboratory using FACS technology allowing for intracellular cytokine secretion on a single cell level. Unexpectedly we found an increased $\mathrm{TNF} \alpha$ secretion capacity of peripheral blood mononuclear (PBM) cells after 
treatment in six patients: the percentage of $\mathrm{CD} 3+\mathrm{TNF} \alpha$ producers increased from a mean of $5.6 \%$ at baseline to $9.9 \%$ at week 2 after non-specific stimulation with PMA/ Ionomycin; one example is shown in figure 2. Similarly, we found a stronger interferon $\gamma$ (IFN $\gamma$ ) secretion after infliximab compared with pretreatment values, which, of interest, had been similarly reported in RA. ${ }^{23}$ Furthermore we have performed experiments to examine the antigen specific cytokine secretion using the $\mathrm{G} 1$ domain of the main proteoglycan, aggrecan, which was reported to induce spondylitis in a mouse model. ${ }^{24}$ Also here we found evidence of a rather increased IFN $\gamma$ secretion after stimulation with recombinant G1 (kindly provided by Y Zhang, Toronto, Canada) after infliximab treatment.

However, the TNF secretion capacity of $\mathrm{PB}$ $\mathrm{CD} 4+$ and $\mathrm{CD} 8+\mathrm{T}$ cells was recently reported to be reduced in AS patients and in HLA B27 positive healthy controls as compared with HLA B27 negative normal persons by our group. ${ }^{25}$ Further experiments suggested that especially the CD8+ subset of experienced effector cells was found to be reduced in HLA B27+ AS patients. This might well not be a real contradiction because it possibly shows that the cytokine pattern of PBM cells is just the reverse of what is happening in the gut, the synovium or in the joints. Accordingly, in patients with acute enteritis we found the lowest TNF secretion while normal healthy people produced the highest amounts. ${ }^{26}$ Thus, low TNF secretion of $\mathrm{PB}$ cells might represent active regulatory suppression in order to prevent damage at other sites or it might be attributable to the fact that effector cells had left the previously inflamed sites. Furthermore, there might be an influence of TNF polymorphisms..$^{25}{ }^{27-29}$ However, these findings have been rather controversial and it is unclear how the polymorphisms relate to secretion capacity.

There is also a discrepancy regarding total lymphocyte counts after treatment with infliximab. Paleolog et $a l^{30}$ reported rather an increase of lymphocyte counts but others found a lower count after infliximab in RA patients. ${ }^{31}$ In our study (see above) PBMCs of six AS patients were examined before, one and two weeks after a single infusion of $5 \mathrm{mg} / \mathrm{kg}$ cA2 . Cells were
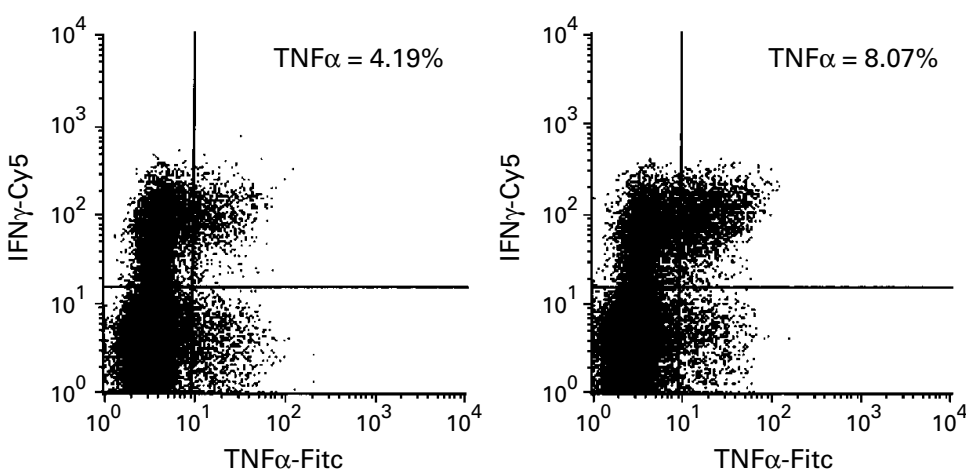

Figure 2 Flow cytometry showing intracellular secretion of TNFa of CD4+ T cells before (left) and one week after treatment with infliximab (right) in a 27 year old patient with ankylosing spondylitis. stimulated with PMA/Ionomycin for six hours, Brefeldin A was added and cells were fixed. FACS analysis was performed by staining for surface CD3. The median total lymphocyte count remained largely unchanged (median from $2.2 / \mathrm{nl}$ initially to $2.0 / \mathrm{nl}$ ) and the relative percentage of CD3 $+\mathrm{T}$ cells decreased slightly (median from $1.4 / \mathrm{nl}$ at baseline to $0.8 / \mathrm{nl}$ ) at week 2 after treatment, respectively. Taken together, these results indicate rather a decrease of the total number of $\mathrm{T}$ cells and an increase of the $\mathrm{T}$ cell $\mathrm{TNF} \alpha$ secretion capacity after anti-TNF $\alpha$ treatment in AS patients. However, we still know little about the possible influence of anti-TNF treatment on T cells and it remains also unclear whether $\mathrm{TNF} \alpha$ surface expression plays a part in AS and in treatment with infliximab. There are some arguments for an influence of infliximab on T cells in Crohn's disease. ${ }^{32}$

On the basis of these discussed results we do not think that a definitive conclusion can be drawn regarding the effect of anti-TNF treatment on a possible TH1/TH2 bias in SpA. In ReA we have reported on a stronger $\mathrm{TH} 2^{33}$ and a weaker TH1 response ${ }^{34}$ at the site of inflammation compared with RA and Lyme disease. We have speculated that this cytokine pattern might facilitate bacterial persistence. However, acute $\operatorname{ReA}$ has a relatively good prognosis and only $10-20 \%$ of the patients, mostly the HLA B27 positive ones, develop ReA over several years. Thus, there are clear differences between the SpA and certainly between different disease stages in SpA. The efficacy of anti-TNF in some severe SpAs certainly argues against a strong systemic $\mathrm{TH} 2$ bias in active and severe disease.

Is there an indication for expensive anti$\mathrm{TNF}$ treatment in SpA? Is the course of disease in $\mathrm{SpA}$ severe enough to justify costly interventions? There are rapidly progressing severe courses of $\mathrm{AS}^{35}$ and it is well known that the majority of the burden of disease develops in the first 10 years. ${ }^{36}{ }^{37}$ This would argue for early treatment. However, there is limited knowledge on prognostic factors in $\mathrm{SpA} .^{38}$ The total burden of disease in AS is incompletely defined but a significant percentage of young AS patients has a chronic recurrent course of disease resulting in significant disability. ${ }^{39}$ There is still a significant diagnostic delay of five years and more and there are almost no studies on AS patients with a disease duration of $<10$ years. Although studying radiographic progression in AS seems to be difficult, ${ }^{40}$ we aim for preventing wide spread spinal ankylosis - an essential factor for disability in AS. Modern imaging techniques such as MRI are promising new tools as activity and outcome parameters in AS. ${ }^{41}$ (Figure 3). In the Berlin infliximab pilot study we observed improvement of inflammatory spinal lesions after infliximab in a rather small number of patients. ${ }^{12}$ As part of a grant by the German Ministery of Research and Technology (BMFT) we hope to be able to also include evaluation of spinal MRI in a large inception cohort study with several hundred patients ${ }^{42}$ 


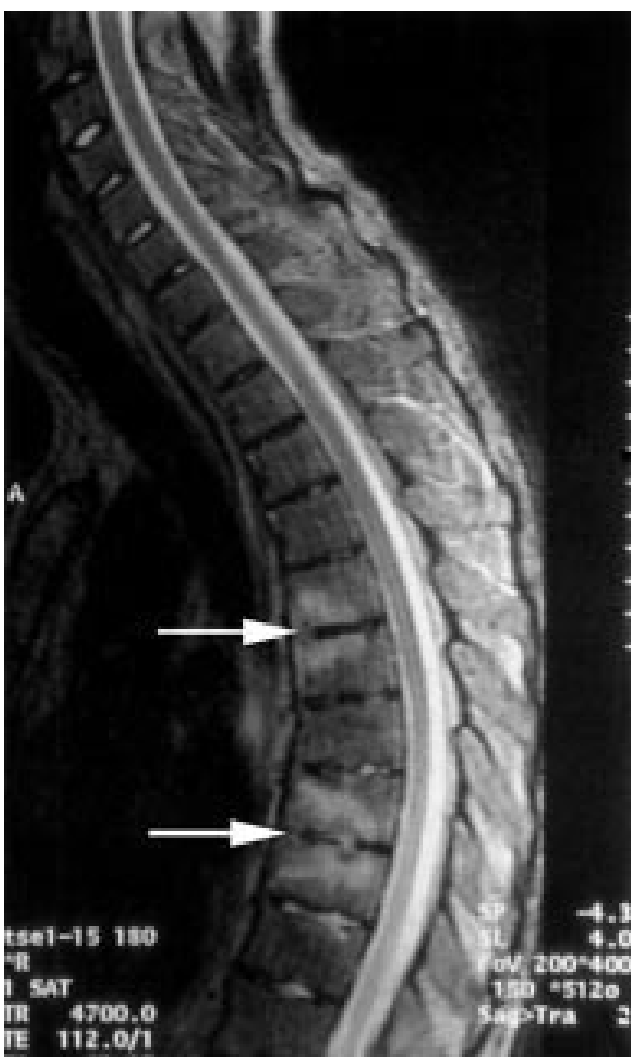

Figure 3 Magnetic resonance imaging (turbo spin echo sequence) of the spine in a 27 year old patient with ankylosing spondylitis, disease duration 12 years, inflammatory back pain grade 5 on a visual analogue scale (0-10), showing severe spondylitis/spondylodiscitis in the thoracic spine at the levels TH 5/6 and TH 8/9.

performed together with other German centres with expertise in $\mathrm{SpA}$.

In summary, treatment directed against $\mathrm{TNF} \alpha$ seems to work not only in RA and Crohn's disease but also in AS and other SpA. However, controlled trials need to be performed to compare the effects with a standard treatment regimen and demonstrate the advantages. As we do not have significant long term experience we do not know about long term side effects. Because of the high costs of treatment we need to study minimal dose requirements but should also think about the possibility of high dose induction treatment that might be even more effective $(20 \mathrm{mg} / \mathrm{kg}$ was probably the highest dose ever tried but no more than 10 $\mathrm{mg} / \mathrm{kg}$ has been used in studies). It is also unclear, whether we have to treat regularly and we have to find out about the optimal intervals? In the randomised controlled trial on AS now planned in Berlin we will treat every sixth week after the induction phase. Initially we should probably treat only very severely affected patients. Later we might also think about very early treatment to interrupt inflammation as soon as possible and prevent cartilage damage to occur.

If the present promising results can be confirmed we have, for the first time, a very effective therapeutic option in severe SpA. This could become a major breakthrough in the treatment of this group of diseases. In AS there might even be hope for prevention of progres- sive ankylosis by effective suppression of inflammation.

1 Leirisalo-Repo M. Prognosis, course of disease, and treatment of the spondyloarth

2 Amor B, Dougados M, Khan MA. Management of refractory ankylosing spondylitis and related spondyloarthropathies. Rheum Dis Clin North Am 1995;21:117-28

3 Bollow M, Fischer T, Reisshauer H, Backhaus M, Sieper J, Hamm B, Braun J. Quantitative analyses of sacroiliac biopsies in spondyloarthropathies: $\mathrm{T}$ cells and macrophages predominate in early and active sacroiliitis- cellularity correlates with the degree of enhancement detected by
magnetic resonance imaging. Ann Rheum Dis 2000;59: magnetic

4 Braun J, Bollow M, Neure L, et al. Use of immunohistologic and in situ hybridization techniques in the examination of sacroiliac joint biopsy specimens from patients with ankylosing spondylitis. Arthritis Rheum 1995;38:499-505.

5 Braun J, Tuszewski M, Ehlers S, et al. Nested PCR strategy simultaneously targeting DNA sequences of multiple bacterial species in inflammatory joint diseases. II. Examination of sacroiliac and knee joint biopsies of patients with spondyloarthropathies and other arthritides. J Rheumtol 1997;24:1101-5.

6 Braun J, Sieper J. The sacroiliac joint in the spondyloarthropathies. Curr Opin Rheumatol 1996;8:275-87.

7 Present D H, Rutgeerts P, Targan S, et al. Infliximab for the treatment of fistulas in patients with Crohn's disease. N treatment of fistulas in patients
Engl J Med 1999;340:1398-405.

8 De Vos M, Cuvelier C, Mielants H, Vexs E, Barbier F, Elewaut A. Ileocolonoscopy in seronegative spondyloarthropathy. Gastroenterology 1989;96:339-44.

9 Maini R, St Clair EW, Breedveld F, et al. Infliximab (chimeric anti-tumour necrosis factor alpha monoclonal antibody) versus placebo in rheumatoid arthritis patients receiving concomitant methotrexate: a randomised phase III trial. ATTRACT Study Group. Lancet 1999;354: 1932-9.

10 Beutler BA. The role of TNF in health and disease. J Rheumatol 1999;26 (suppl 57):16-21.

11 Cope AP. Regulation of autoimmunity by proinflammatory cytokines. Curr Opin Immunol 1998;10:669-76.

12 Brandt J, Haibel H, Cornely D, et al. Successful treatment of active ankylosing spondylitis with the anti-tumor necrosis factor $\alpha$ monoclonal antibody infliximab. Arthritis Rheum 2000; 43:1346-52

13 Van den Bosch F, Kruithof E, Baeten D, De Keyser F, Mielants H, Veys E. Effects of chimeric monoclonal antibody to tumor necrosis factor-a (infliximab) in spondyloarthropathy: an open pilot study. Ann Rheum Dis 2000;59: 428-33

14 Weinblatt ME, Kremer JM, Bankhurst AD, et al. A trial of etanercept, a recombinant tumor necrosis factor receptor: Fc fusion protein, in patients with rheumatoid arthritis receiving methotrexate. N Engl J Med 1999;28:253-9.

15 Calin A, Nakache J-P, Gueguen A, Zeidler H, Mielants H, Dougados $M$. Defining disease activity in ankylosing spondylitis: is a combination of variables (Bath Ankylosing
Spondylitis Disease Activity Index) an appropiate instrument. Rheumatology 1999;38:878-82.

16 Ward M, Kuzis S. Treatment used by patients with ankylosing spondylitis. Comparison with the treatment preferences ing spondylitis. Comparison with the treatment pre

17 Braun J, Sieper J. Anti-TNF $\alpha$ - a new dimension in the Braun J, Sieper J. Anti-TNF $\alpha-$ a new dimension in the
pharmacotherapy of SpA. Ann Rheum Dis 2000;59:404-7. 18 Antoni C, Dechant C, Lorenz H, Olgivie A, KaldenAntoni C, Dechant C, Lorenz H, Olgivie A, Kalden-
Nemeth D, Kalden J. Successful treatment of severe psoriasis arthritis with infliximab. Arthritis Rheum 1999;42 (suppl):S371

19 Mease P, Goffe B, Metz J, Vanderstoep A, Fink B, Burge DJ. Etanercept in the treatment of psoriatic arthritis and psoriosis: a randomised trial. Lancet 2000;356:358-90.

20 Braun J, Bollow M, Remlinger G, et al. Prevalence of spondylarthropathies in HLA-B27 positive and negative blood donors. Arthritis Rheum. 1998;41:58-67.

21 Brandt J, Bollow M, Haberle J, et al. Studying patients with inflammatory back pain and arthritis of the lower limbs clinically and by magnetic resonance imaging: many, but not all patients with sacroiliitis have spondyloarthropathy. not all patients with sacroiliitis
Rheumatology 1999;38:831-6.

22 Charles P, Elliott MJ, Davis D, et al. Regulation of cytokines, cytokine inhibitors, and acute-phase proteins following anti-TNF-alpha therapy in rheumatoid arthritis. J Immunol 1999;163:1521-8

23 Maurice MM, van der Graaff WL, Leow A, Breedveld FC, van Lier RA, Verweij CL. Treatment with monoclonal antitumor necrosis factor alpha antibody results in an accumulation of Th1 CD4+ T cells in the peripheral blood of patients with rheumatoid arthritis. Arthritis Rheum 1999; 42:2166-73.

24 Leroux JY, Guerassimov A, Cartman A, et al. Immunity to the G1 globular domain of the cartilage proteoglycan aggrecan can induce inflammatory erosive polyarthritis and spondylitis in $\mathrm{BALB} / \mathrm{c}$ mice but immunity to $\mathrm{G} 1$ is inhibited by covalently bound keratan sulfate in vitro and in vivo. J Clin Invest 1996;97:621-32.

25 Rudwaleit M, Siegert S, Thiel A, et al. Low $\mathrm{T}$ cell production of TNF $\alpha$ and IFN $\gamma$ in ankylosing spondylitis: its relation to HLA B27 and influence of the TNF-308 gene polymorphism. Ann Rheum Dis (in press) 
26 Braun J, Yin Z, Spiller I, et al. A low TNF $\alpha$-secretion of peripher blood mononuclear cells but no other T helper 1
or 2 cytokines correlates with chronicity in reactive arthrior 2 cytokines correlates with chronicity

27 Hoehler T, Schaper T, Schneider PM, Meyer zum Buschenfelde $\mathrm{KH}$, Maerker-Hermann E. Association of differen tumor necrosis factor alpha promoter allele frequencies with ankylosing spondylitis in HLA-B27 positive individuals. Arthritis Rheum 1998;41:1489-92.

28 Kaijzel EL, Brinkman BM, van Krugten MV, ewt al. Polymorphism within the tumor necrosis factor alpha (TNF) promoter region in patients with ankylosing spondylitis. Hum Immunol 1999;60:140-4.

29 McGarry F, Walker R, Sturrock R, Field M. The -308.1 polymorphism in the promoter region of the tumor necrosis factor gene is associated with ankylosing spondylitis independent of HLA-B27. J Rheumatol 1999;26:1110-16.

30 Paleolog EM, Hunt M, Elliott MJ, Feldmann M, Maini RN, Woody JN. Deactivation of vascular endothelium by monoclonal anti-tumor necrosis factor alpha antibody in rheumatoid arthritis. Arthritis Rheum 1996;39:1082-91.

31 Ohsima S, Saeki Y, Mima T, et al. Long-term follow up of the changes in circulating cytokines, soluble cytokine receptors, and white blood cell counts in patients with rheumatoid arthritis after monoclonal anti-TNFa antibody therapy. J Clin Immunol 1999;19:305-13.

32 Van Deventer SJH. Anti-TNF antibody treatment of Crohn's disease. Ann Rheum Dis 1999;58:114-20.

33 Simon AK, Seipelt E, Sieper J. Divergent T cell cytokine patterns in inflammatory arthritis. Proc Natl Acad Sci USA $1994 ; 91: 8562-6$
34 Yin Z, Braun J, Neure L, et al. Crucial role of interleukin-10/interleukin-12 balance in the regulation of the type $2 \mathrm{~T}$ helper cytokine response in reactive arthritis. Arthritis Rheum 1997;40:1788-97.

35 Ward M. Health-related quality of life in ankylosing spondylitis: a survey of 175 patients. Arthritis Care Res 1999;12:247-55.

36 Carette S, Graham D, Little H, Rubenstein J, Rosen P. The natural disease course of ankylosing spondylitis. Arthritis Rheum 1983;26:186-90.

37 Gran JT, Skomsvoll JF. The outcome of ankylosing spondylitis: a study of 100 patients. Br J Rheumatol 1997; 36:766-71.

38 Amor B, Santos RS, Nahal R, Listrat V, Dougados M. Predictive factors for the longterm outcome of spondyloarthropathies. J Rheumatol 1994;21:1883-7.

39 Zink A, Braun J, Listing A, Wollenhaupt J, and the German Colloborative Research Centers. Disability and handicap in rheumatoid arthritis and ankylosing spondylitis -results from the German rheumatological database. German Collaborative Arthritis Centers. J Rheumatol 2000;27:613-22.

40 Spoorenberg A, de Vlam K, van der Heijde D, et al. Radiologic scoring methods in ankylosing spondylitis: reliability logic scoring methods in ankylosing spondylitis: reliability 26:997-1002.

41 Braun J, Bollow M, Sieper J. Radiologic diagnosis and pathology of the spondyloarthropathies. Rheum Dis Clin North Am 1998;24:697-735.

42 Braun J, Sieper J. Inception cohort for early spondyloarthropathies. Z Rheumatol 2000;59:117-21. 